\title{
Efektivitas Pelatihan Motivasi untuk Meningkatkan Motivasi Kerja Pekerja Outsourcing Sebagai Cleaning Service di UIN Imam Bonjol Padang
}

\author{
Winbaktianur, Nadya Ulfa Risya Putri \\ Dosen UIN Imam Bonjol Padang
}

Diterima: Juni 2017. Disetujui: Oktober 2017. Dipublikasikan: Desember 2017

\begin{abstract}
This article aims to determine the work motivation of outsourced workers before being given motivation training, knowing the work motivation of outsourced workers after being given motivation training. Then know whether there is an influence of motivation training to improve work motivation and know the smoothness of motivation training. The research method used is a pure experimental method, with pretest-posttest control group design research design. The subjects of the research are outsourced workers as cleaning service in UIN Imam Bonjol Padang totaling 30 people. Subjects were selected based on randomization measured using a work motivation scale, which was divided into two groups: the experimental group and the control group. Each group has 15 people. The experimental group was given treatment in the form of motivation training, while the control group did not. Based on the pretest results, the experimental group and the control group showed moderate work motivation. In the posttest results, the experimental group experienced improvement after treatment. While the control group that was not given treatment there was no increase, even the decrease of work motivation. The result of the research proves that the giving of motivation training has an effect on the increase of work motivation to the outsourced workers as cleaning service in UIN Imam Bonjol Padang. The training implementation questionnaire proved that motivational training was going well for the participants.
\end{abstract}

Keywords: Training Motivation, Work Motivation, Outsourcing Workers

\begin{abstract}
Abstrak: Artikel ini bertujuan untuk mengetahui motivasi kerja pekerja outsourcing sebelum diberi pelatihan motivasi, mengetahui motivasi kerja pekerja outsourcing sesudah diberi pelatihan motivasi. Kemudian mengetahui adakah pengaruh pelatihan motivasi untuk meningkatkan motivasi kerja dan mengetahui kelancaran pelatihan motivasi. Metode penelitian yang digunakan adalah metode eksperimen murni, dengan desain penelitian pretestposttest control group design. Subjek penelitian adalah pekerja outsourcing sebagai cleaning service di UIN Imam Bonjol Padang berjumlah 30 orang. Subjek dipilih berdasarkan randomisasi yang diukur menggunakan skala motivasi kerja, yang dibagi menjadi dua kelompok yaitu kelompok eksperimen dan kelompok kontrol. Masingmasing kelompok berjumlah 15 orang. Kelompok eksperimen diberikan treatment berupa pelatihan motivasi, sementara kelompok kontrol tidak. Berdasarkan hasil pretest, kelompok eksperimen dan kelompok kontrol menunjukkan motivasi kerja kategori sedang. Pada hasil posttest, kelompok eksperimen mengalami peningkatan setelah diberikan treatment. Sementara kelompok kontrol yang tidak diberi treatment tidak terdapat peningkatan, bahkan penurunan motivasi kerja. Hasil penelitian membuktikan pemberian treatment berupa pelatihan motivasi berpengaruh terhadap peningkatan motivasi kerja pada pekerja outsourcing sebagai cleaning service di UIN Imam Bonjol Padang. Kuisioner pelaksanaan pelatihan membuktikan bahwa pelatihan motivasi berlangsung lancar bagi peserta.
\end{abstract}

Kata Kunci: Pelatihan Motivasi; Motivasi; Kerja; Pekerja; Outsourcing

\section{Pendahuluan}

Pekerjaan yang dijalani oleh setiap manusia bertujuan untuk memenuhi kebutuhan hidup serta keberlangsungan hidupnya. Untuk pemenuhan kebutuhan tersebut dibutuhkan biaya yang 
tidak sedikit. Dikarenakan banyak aspek yang harus dipenuhi berupa kebutuhan primer, sekunder dan tersier. Kebutuhan tersebut dapat diwujudkan dengan menggunakan alat tukar yang salah satunya adalah uang. Untuk dapat memperoleh uang, seseorang harus memiliki pekerjaan atau membangun usaha dengan memberikan pelayanan jasa atau barang, yang dibayarkan dengan uang. Dalam mencari pekerjaan yang dilakukan seseorang, hal ini sejalan dengan tugas perkembangan pada masa dewasa dini yaitu dipusatkan pada harapan-harapan masyarakat dan mencakup mendapatkan suatu pekerjaan, memilih seorang teman hidup, belajar hidup bersama dengan suami atau isteri membentuk suatu keluarga, membesarkan anak-anak, mengelola sebuah rumah tangga, menerima tanggung jawab sebagai warga negara dan bergabung dalam suatu kelompok sosial yang cocok (Hurlock, 2002).

Menjadi pekerja dengan status tenaga kerja outsourcing merupakan salah satu pilihan. Outsourcing (Restu K, 2011:1) diartikan sebagai pemindahan atau pendelegasian berbagai proses bisnis kepada suatu badan penyedia jasa, dimana badan penyedia jasa tersebut melakukan proses administrasi dan manajemen berdasarkan definisi serta kriteria yang telah disepakati oleh kedua pihak. Dalam perkembangannya, perusahaan yang menggunakan sistem outsourcing akan menyebabkan kedudukan dan hubungan kerja antara pekerja dan pengusaha menjadi tidak seimbang. Hal ini berdampak kepada posisi pekerja menjadi semakin lemah karena tidak ada kepastian kerja, kepastian upah, jaminan sosial, jaminan kesehatan, pesangon, jika terjadi pemutusan hubungan kerja, tunjangan- tunjangan dan kepastian lainnya.

Selanjutnya raktek outsourcing lebih menguntungkan bagi perusahaan tetapi tidak demikian dengan pekerja yang selama ini lebih banyak dirugikan, karena hubungan kerja selalu dalam bentuk tidak tetap atau kontrak, upah lebih rendah, jaminan sosial kalaupun ada hanya sebatas minimal, tidak adanya job security serta tidak adanya jaminan pengembangan karir, sehingga dalam keadaan seperti itu pelaksanaan outsourcing menyengsarakan pekerja. Pelaksanaan outsourcing banyak dilakukan untuk menekan biaya pekerja (labour cost) dengan perlindungan dan syarat kerja yang diberikan jauh dibawah dari yang seharusnya diberikan sehingga sangat merugikan perkerja.

Ketua Konfederasi Serikat Pekerja Indonesia (KSPI) Said Iqbal menyatakan dalam suatu majalah eloktronik, bahwa bulan Januari hingga Maret memperkirakan adanya pemutusan hubungan kerja disingkat dengan PHK yang mencapai 10.000 pekerja. Dapat diperkirakan kembali bahwa terjadinya PHK dengan jumlah 50.000 pekerja pada tahun lalu 2015 (http://bisnis.liputan6.com/read /2428536/kspi-perkirakan-akan-ada-phk-besar diunduh pada 17 Juni 2016). Fenomena tersebut membuktikan bahwasanya pekerja outsourcing dapat diberhentikan sewaktu-waktu. Begitu banyak kerugian yang didapat ketika seseorang menjadi pekerja outsourcing dibandingkan mereka yang bekerja sebagai karyawan tetap. May Day merupakan hari buruh dimana tepat tanggal $01 \mathrm{Mei}$ adalah hari buruh sedunia. Hari tersebut dimanfaatkan oleh para buruh di seluruh Indonesia untuk menyampaikan aspirasi mereka. Seperti meminta kenaikan gaji yang mereka nilai sangat rendah. Ratusan buruh dari beberapa elemen serikat buruh kembali berdemo di sekitar Istana Kepresidenan, mereka menuntut agar pemerintah menghapus upah kecil, dengan mencabut Peraturan Pemerintah Nomor 78 Tahun 2015 tentang pengupahan, demo ini terjadi Senin (02/05/2016). Tidak hanya di Istana Negara, ratusan ribu buruh juga melakukan demo di berbagai tempat di Jakarta dalam rangka memperingati hari buru dengan menyampaikan tuntutannya (http://news.liputan6.com/read/2497884/kembali-berdemo-di-istana-buruh- $\quad$ tuntut-upah- 
murahdihapus?Utm source=Search\&utm medium=SiteSearch\&utm_campaign=Origi nal, di unduh 13 Juni 2016). Selain dari para buruh yang mengikuti demo, buruh yang tergabung dalam Konfederasi Serikat Pekerja Indonesia (KSPI) meminta pemerintah untuk menaikkan upah minimum propinsi (UMP) 2017 sebesar Rp 650 ribu. Presiden KSPI Said Iqbal mengatakan, ada beberapa dasar tuntutan buruh soal kenaikan upah minimum tersebut. Pertama, jika dihitung sejak tahun ini, seharusnya UMP di DKI Jakarta harusnya sebesar Rp 3,5 juta. Namun pada akhir tahun lalu Gubernur DKI Jakarta Basuki Tjahja Purnama (Ahok) menetapkan UMP 2016 sebesar Rp 3,1 juta. "Secara hitung-hitungan anggota Dewan Pengupahan dari unsur buruh, harusnya upah minimum

2016 itu Rp 3,5 juta. Tetapi diputuskanUMP tahun ini Rp 3,1 juta. Berarti masih kurang Rp 400 ribu” ujar Said Iqbal di Jakarta, Jumat (27/5/2016) (http://bisnis. liputan6.com/news/read/2517422/buruh- tuntutan-buruh-ump-2017-naik-rp-650-ribu- inialasannya, di unduh 13 Juni 2016).

Kondisi pemberian gaji atau upah sangat memprihatinkan dapat dilihat dari Grafik berikut ini :

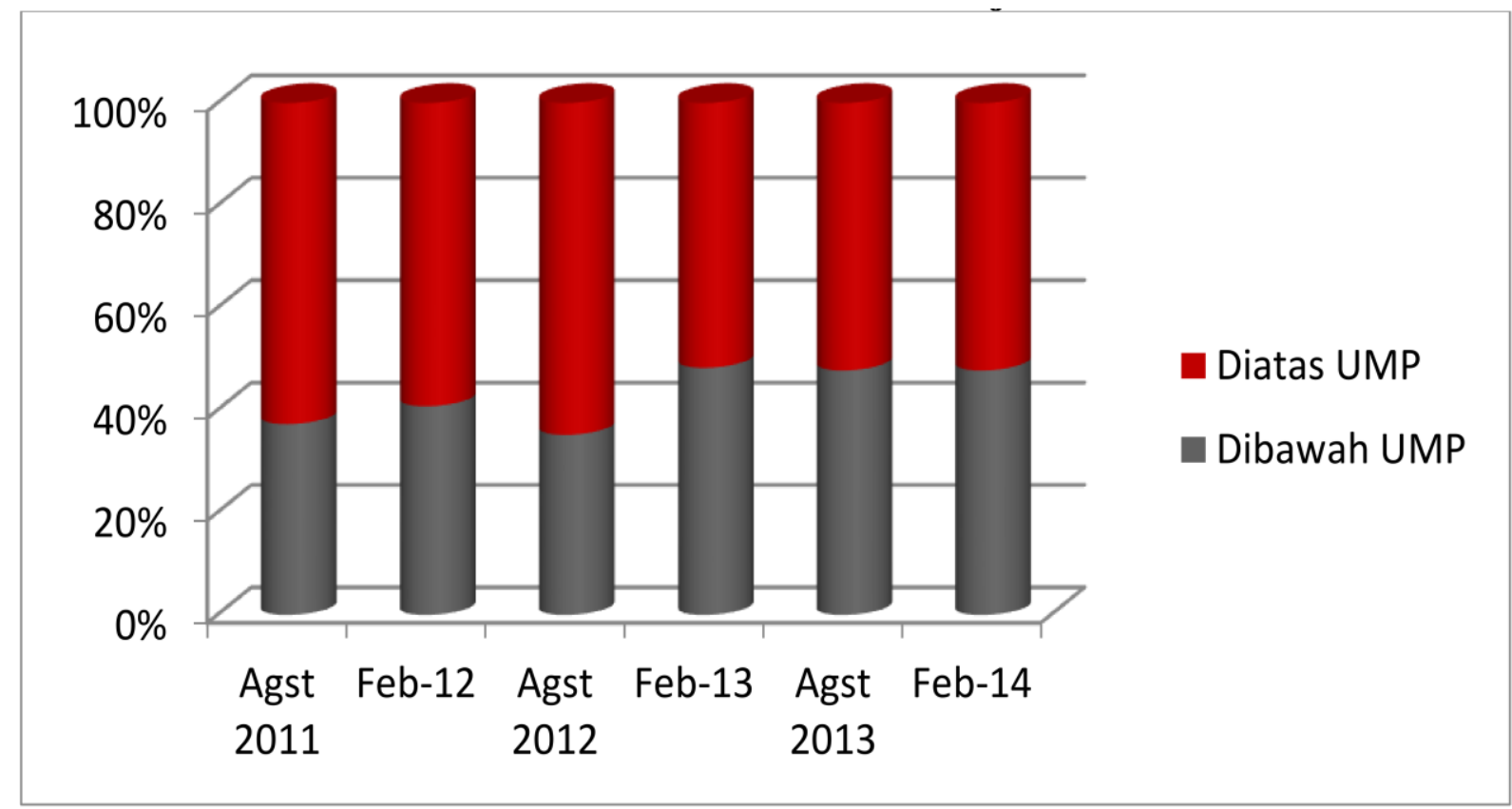

(Sumber : BPS, 2014)

Gambar 1. Gaji atau Upah Buruh

Dari grafik tersebut tergambar bahwa masih banyak buruh yang upahnya tidak sesuai dengan Upah Minimum Provinsi selanjutnya disingkat menjadi (UMP) yang telah di tetapkan oleh Kementrian Tenaga Kerja. Sedangkan di Provinsi Sumatera Barat sesuai dengan Surat Keputusan Gubernur Sumbar Nomor: 562-781-2012 tanggal 6 November 2012 menyatakan 
bahwa UMP di Provinsi Sumatera Barat yaitu Rp.1.350.000. Namun masih terdapat buruh atau pekerja outsourcing yang di gaji kecil dari UMP.

Pelatihan Motivasi

\section{A. Pelatihan}

Motivasi dapat mendasari seseorang dalam bekerja dan dapat diberikan melalui pelatihan (training), Menurut Rivai \& Sagala (2013:212-233) pelatihan adalah proses secara sistematis mengubah tingkah laku pegawai untuk mencapai tujuan organisasi.

Pelatihan berkaitan dengan keahlian dan kemampuan pegawai untuk melaksanakan pekerjaan saat ini. Pelatihan memiliki orientasi saat ini dan membantu pegawai untuk mencapai keahlian dan kemampuan tertentu agar berhasil dalam melaksanakan pekerjaannya. Sedangkan program pelatihan formal adalah usaha pemberi kerja untuk memberikan kesempatan kepada pegawai untuk memperoleh pekerjaan atau bidang tugas yang sesuai dengan kemampuan, sikap dan kemampuannya. Menurut Rini \& Widiana (2011:8) pelatihan motivasi adalah suatu kegiatan yang bermaksud untuk dapat memperbaiki dan memperkembangkan sikap, tingkah laku, keterampilan dan pengetahuan dari para karyawan, sesuai keinginan dari perusahaan yang bersangkutan untuk mendorong seseorang melakukan serangkaian kegiatan yang mengarah ketercapainya tujuan tertentu.

Pelatihan adalah setiap usaha untuk memperbaiki performansi pekerja pada suatu pekerjaan tertentu yang sedang menjadi tanggung jawab, atau satu pekerjaan yang ada kaitannya dengan pekerjaannya (Gomes, 2002:197). Sedangkan Andrew E. Sikula mengatakan bahwa pelatihan adalah suatu proses pendidikan jangka pendek yang mempergunakan prosedur sistematis dan terorganisir dimana managerial mempelajari pengetahuan dan keterampilan teknis dalam tujuan terbatas (Mangkunegara, 2009:44). Pelatihan merupakan proses untuk membentuk dan membekali karyawan dengan menambah keahlian, kemampuan, pengetahuan dan perilakunya (Kasmir, 2016:126). Pendapat lain menyatakan (Sulistiyani \& Rosidah, 2009:219-220) bahwa pelatihan adalah proses sistematik mengubah perilaku para pegawai dalam suatu arah guna meningkatkan tujuan-tujuan organisasional. Sedangkan menurut Simamora menjelaskan bahwa pelatihan (training) diarahkan untuk membantu karyawan menunaikan kepegawaian mereka saat ini secara lebih baik.

\section{B. Motivasi}

Motivasi (Usman, 2013:275-276) berasal dari bahasa Latin movere, yang berarti bergerak atau dalam bahasa Inggrisnya, to move. Menurut Schunk, et al, motivasi adalah proses melalui kegiatan pencapaian tujuan yang telah mendorong dan berkelanjutan. Motivasi merupakan keinginan yang terdapat pada diri seseorang yang merangsangnya untuk melakukan tindakantindakan atau sesuatu yang menjadi dasar atau alasan seseorang untuk berperilaku. Menurut Hasibuan (2014:95) motivasi adalah pemberian daya penggerak yang menciptakan kegairahan kerja seseorang, agar mereka mau bekerja sama, bekerja efektif dan terintegrasi dengan segala daya upayanya untuk mencapai kepuasan.

Murray (Wijono, 2014:20-21) mendefinisikan motivasi sebagai sebuah faktor yang mengakibatkan munculnya, memberi arah dan menginterpretasikan perilaku seseoarang. Hal tersebut biasanya dibagi oleh dua komponen, yaitu dorongan dan penghapusan. Dorongan 
mengacu pada proses internal yang mengakibatkan seseorang itu bereaksi. Penghilangan mengacu pada terhapusnya motif seseorang disebabkan individu tersebut telah berhasil mencapai satu tujuan atau mendapat ganjaran memuaskan. Kemudian Lawler memberi definisi motivasi sebagai perilaku yang dikontrol oleh pengontrolan pusat manusia yang mengarahkan individu untuk mencapai suatu tujuan.

Menurut Munandar (2008:323) motivasi adalah suatu proses dimana kebutuhankebutuhan mendorong seseorang untuk melakukan serangkaian kegiatan yang mengarah tercapainya tujuan tertentu. Maslow berpendapat bahwa kondisi manusia berada dalam kondisi mengejar yang bersinambung. Jika satu kebutuhan dipenuhi, langsung kebutuhan tersebut diganti oleh kebutuhan lain. Proses berkeinginan secara tidak berhenti memotivasi kita sejak lahir sampai meninggal. Maslow selanjutnya mengajukan bahwa ada lima kelompok kebutuhan, yaitu kebutuhan faali (fisiologikal), rasa aman, sosial, harga diri, dan aktualisasi diri.

Motivasi menyangkut perilaku menusia dan merupakan sebuah unsur yang vital dalam sebuah manajemen. Motivasi dapat didefinisikan sebagai membuat seseorang menyelesaikan pekerjaan dengan semangat karena orang itu ingin melakukannya. Pendekatan-pendekatan dasar terhadap motivasi berbeda-beda dikalangan para manajer. Terdapat tiga pendekatan umum: (a) lingkungan, (b) produktivitas, dan (c) pemuasan kebutuhan- kebutuhan (Terry \& Rue, 2009: 168-169). Wahjosumidjo (1987:173-180) berpendapat motivasi sebagai proses psikologis timbul diakibatkan oleh faktor di dalam diri seseorang itu sendiri yang di sebut intrinsik dan faktor diluar diri yang disebut faktor ekstrinsik. Faktor di dalam diri seseorang dapat berupa kepribadian, sikap, pengalaman, pendidikan, atau berbagai harapan, cita-cita yang menjangkau ke masa depan. Sedangkan faktor di luar diri, dapat ditimbulkan oleh berbagai sumber, bisa karena pengaruh pemimpin, kolega atau faktor-faktor lain yang sangat kompleks. Tetapi baik faktor intrinsik maupun faktor luar motivasi timbul karena adanya rangsangan. Dapat disimpulkan bahwa motivasi sebagai konsep manajemen dalam kaitannya dengan kehidupan organisasi dan kepemimpinan adalah dorongan kerja yang timbul pada diri seseorang untuk berperilaku dalam mencapai tujuan yang telah ditentukan.

Menurut Indriyo Gitosudarmo dan Nyoman Sudita (Ardana dkk, 2008:30) motivasi adalah faktor-faktor yang ada dalam diri seseorang yang menggerakkan, mengarahkan perilakunya untuk memenuhi tugas tertentu. Robbins dan Coulter berpendapat bahwa motivasi adalah kesediaan untuk mengeluarkan tingkat upaya yang tinggi untuk tujuan organisasi yang dikondisikan oleh kemampuan upaya itu dalam memenuhi beberapa kebutuhan individu tertentu. Sedangkan menurut Ardana motivasi adalah suatu kebutuhan yang mendorong seseorang untuk berbuat "sesuatu".

Sementara menurut Wexley \& Yuki (2005:98-101) motivasi didefinisikan sebagai proses dimana perilaku diberikan energi dan diarahkan. Kebutuhan yang relevan dengan perilaku dalam organisasi meliputi, (1) kebutuhan kelangsungan hidup, (2) kebutuhan keamanan, perlindungan dari ancaman bahaya fisik atau kurangnya pendapatan, (3) kebutuhan berkelompok, keinginan manusia untuk menjalin ikatan kelompok dan hubungan antar pribadi, (4) kebutuhan penghargaan, (5) kebutuhan kebebasan, (6) kebutuhan kecakapan dan keberhasilan.

\section{Pelatihan Motivasi}

Menurut Rini \& Widiana (2011:8) pelatihan motivasi adalah suatu kegiatanyang bermaksud untuk dapat memperbaiki dan memperkembangkan sikap, tingkah laku, keterampilan 
dan pengetahuan dari para karyawan, sesuai keinginan dari perusahaan yang bersangkutan untuk mendorong seseorang melakukan serangkaian kegiatan yang mengarah ketercapaiannya tujuan tertentu. Berdasarkan dari pengertian masing- masing yang telah dijelaskan, dapat disimpulkan bahwa pelatihan motivasi adalah usaha dalam merubah perilaku pegawai yang didasari oleh dorongan dalam dan luar diri, melalui proses sistematis dalam mencapai tujuan organisasi.

\section{Metode Pelatihan Motivasi}

Metode yang dipilih hendaknya disesuaikan dengan jenis pelatihan yang akan dilaksanakan dan yang dapat dikembangkan oleh suatu perusahaan. Menurut Rivai dkk (2013:226-233) terdapat metode pelatihan di antaranya adalah:

1. On the job $(O T)$ atau disebut juga dengan pelatihan dengan instruksi pekerjaan sebagai suatu metode pelatihan dengan cara para pekerja atau calon pekerja ditempatkan dalam kondisi pekerjaan yang riil, dibawah bimbingan dan supervisi dari pegawai yang telah berpengalaman atau seorang supervisor.

2. Rotasi digunakan untuk pelatihan silang (cross-train) bagi karyawan agar mendapatkan variasi kerja, para pengajar memindahkan para peserta pelatihan dari tempat kerja yang satu ke tempat kerja yang lainnya.

3. Magang melibatkan pembelajaran dari pekerja yang lebih berpengalaman, dan dapat ditambahkan pada teknik off the job training.

4. Ceramah kelas dan presentasi video. Ceramah adalah pendekatan terkenal karena menawarkan sisi ekonomis dan material organisasi. Umpan balik dan partisipasi dapat meningkat dengan adanya diskusi selama ceramah. Televisi, film, slide dan film pendek sama dengan ceramah.

5. Pelatihan Vestibule, Wilayah atau Vestibule terpisah dibuat dengan peralatan yang sama dengan yang digunakan dalam pekerjaan. Cara ini memungkinkan adanya transfer, repitisi, dan partisipasi serta material perusahaan.

6. Permainan Peran dan Model Perilaku Permainan peran adalah alat yang mendorong peserta untuk membayangkan identitas lain.

7. Case Study, Metode kasus adalah metode pelatihan yang menggunakan deskripsi tertulis dari suatu permasalahan riil yang dihadapi oleh perusahaan atau perusahaan lain.

8. Simulasi, Permainan simulasi dapat dibagi menjadi dua macam. Pertama, simulasi yang melibatkan simulator yang bersifat mekanik (mesin) yang mengandalkan aspek-aspek utama dalam suatu situasi kerja. Kedua, simulasi komputer, metode ini sering berupa games.

9. Belajar Mandiri dan Proses Belajar Terprogram, Materi instruksional yang direncanakan secara tepat dapat digunakan untuk melatih dan mengembangkan para karyawan dan sangat berguna bagi karyawan yang berjauhan teknik belajar mandiri berkisar pada cara manual sampai kaset rekaman atau vidio.

10. Praktik Laboratorium, Pelatihan ini dilakukan dilaboratorium dirancang untuk meningkatkan keterampilan interpersonal.

11. Pelatihan Tindakan (Action Learning), Pelatihan ini dalam kelompok kecil yang berusaha mencari solusi masalah nyata yang dihadapi oleh perusahaan, dibantu oleh fasilitator (diluar dari perusahaan).

12. Role Playing, Metode ini merupakan perpaduan antara metode kasus dan program pengembangan sikap. 
13. In-basket Technique, Metode ini memberikan peserta materi yang berisikan berbagai informasi, seperti email khusu dari manajer, dan daftar telepon.

14. Management Game, Metode ini menekankan pada pengembangan kemampuan problemsolving.

15. Behavior Modeling, Modeling sebagai salah satu proses yang bersifat psikologis mendasar dimana pola-pola baru dari suatu perilaku dapat diperoleh sedangkan pola yang sudah ada dapat diubah.

16. Outdoor Oriented Programs, Program ini biasanya dilakukan disuatu wilayah yang terpencil dengan melakukan kombinasi antara kemampuan di luar kantor dengan kemampuan di ruang kelas.

Metode yang digunakan adalah ceramah dan penampilan video, yang diselingi dengan ice breaking. Pelatihan motivasi pada penelitian ini dilakukan oleh trainer yang memberikan materi. Materi yang disampaikan berisikan teori motivasi kerja dari Abraham Maslow, standar dari suatu kebersihan, dan beberapa penyampaian ayat Al-Quran mengenai rezeki.

\section{Motivasi Kerja}

Motivasi kerja menurut Anoraga (2009:35-40) adalah sesuatu yang menimbulkan semangat atau dorongan kerja. Menurut Herzberg, sistem kebutuhan- kebutuhan orang yang mendasari otivasinya, dapat dibagi menjadi dua golongan:

a. Hygiene Factors, meliputi status, hubungan antar manusia, supervisi, peraturan-peraturan dan administrasi, jaminan dalam pekerjaan, kondisi kerja, gaji, kehidupan pribadi.

b. Motivational Factors (Motivators), meliputi pekerjaannya sendiri, achievement, kemungkinan untuk berkembang, tanggung jawab, kemajuan dalam jabatan, pengakuan.

c. Seseorang dalam bekerja terdapat suatu unsur pendorong yang disebut motivasi kerja, dimana Anoraga (Budiartha dkk, 2015) menyatakan bahwa motivasi kerja ialah suatu model dalam menggerakkan dan mengarahkan para karyawan agar dapat melaksanakan tugasnya masing-masing dalam mencapai sasaran dengan penuh kesadaran, kegairahan dan bertanggung jawab. Newstrom menyatakan bahwa motivasi kerja adalah kesediaan individu untuk mengeluarkan upaya yang tinggi untuk mencapai tujuan organisasi. Sementara itu Sedarmayanti (Sugesti, 2012:32) berpendapat bahwa motivasi kerja merupakan seperangkat kekuatan baik yang berasal dari dalam diri maupun dari luar diri seseorang yang mendorong untuk memulai berperilaku kerja, sesuai dengan format, arah, intensitas dan jangka waktu tertentu.

Sementara menurut Usman (2013:276) motivasi kerja diartikan sebagai keinginan atau kebutuhan yang melatarbelakangi seseorang sehingga ia terdorong untuk bekerja. Motivasi seseorang ditentukan oleh intensitas motifnya, motif yang dimaksud adalah kebutuhan (need), keinginan, dorongan ataupun impuls. Kemudian Samsudin (Afrianti, 2012:13) menyatakan bahwa motivasi kerja adalah sesuatu yang menimbulkan dorongan atau semangat kerja. Sedangkan Wijono (2014:25) mendefinisikan motivasi kerja merupakan kesungguhan atau usaha dari individu untuk melakukan pekerjaannya guna mencapai tujuan organisasi di samping tujuannya sendiri.

\section{Pekerja Outsourcing}


Outsourcing diartikan sebagai (Restu,2011:1) pemindahan atau pendelegasian berbagai proses bisnis kepada suatu badan penyedia jasa, dimana badan penyedia jasa tersebut melakukan proses administrasi dan manajemen berdasarkan definisi serta kriteria yang telah disepakati oleh para pihak. Dalam perkembangannya, perusahaan yang menggunakan sistem outsourcing akan menyebabkan kedudukan dan hubungan kerja antara pekerja dan pengusaha menjadi tidak seimbang. Hal ini berdampak kepada posisi pekerja menjadi semakin lemah karena tidak ada kepastian kerja, kepastian upah, jaminan sosial, jaminan kesehatan, pesangon, jika terjadi pemutusan hubungan kerja, tunjangan-tunjangan dan kepastian lainnya. Outsourcing (Tunggal, 1995:134) juga diartikan sebagai proses membeli suku cadang atau komponen dari pemasok luar dari pada memproduksi sendiri. Sedangkan menurut Husni (Lumingas, 2013: 150-151) mengartikan bahwa outsourcing merupakan bisnis kemitraan dengan tujuan memperoleh keuntungan bersama. Salah satu bentuk pelaksanaan outsourcing adalah melalui perjanjian pemborong pekerjaan. Dalam menjalankan kegiatannnya, perusahaan pemborong memiliki hubungan kerja dengan pekerja, sedangkan hubungan antar perusahaan pengguna dan perusahaan pemborong hanyalah terkait dengan pekerjaan yang diborongkan tersebut. Hubungan kerja yang terbentuk dalam penyerahan sebagian pelaksana pekerja kepada perusahaan (outsourcing) berdasarkan UU No. 13 Tahun 2003, baik melalui pemborongan kerja maupun penyedia jasa pekerja/buruh adalah tetap berdasarkan perjanjian kerja secara tertulis antara perusahaan pemborong pekerja atau perusahaan penyedia jasa pekerja/buruh dengan pekerja/buruh yang dipekerjakan. Outsourcing diberikan pengertian pendelegasian operasi dan manajemen harian suatu proses bisnis pada pihak luar.

Praktek outsourcing (Restu, 2011:5) dalam perkembangannya banyak pihak yang menolak pemberlakuan sistem outsourcing, karena sistem outsourcing dianggap merugikan pekerja dan hanya menguntungkan perusahaan. Hal ini disebabkan karena outsourcing membuat perusahaan lebih memilih mengangkat pekerja secara outsourcing dari pada pekerja tetap karena melalui outsourcing perusahaan dapat menghemat dalam membayar sumber daya manusia (SDM) yang bekerja diperusahaan yang bersangkutan. Adanya beberapa masalah pokok praktik outsourcing yang tidak benar, pembayaran gaji yang tidak sesuai, tidak adanya tunjangantunjangan (kesehatan, masa kerja), kontrak yang tidak diperpanjang.

\section{Metode Penelitian}

Penelitian yang digunakan dalam penelitian ini adalah penelitian kuantitatif dengan jenis penelitian eksperimental yang menilai bahwa adanya pengaruh pelatihan motivasi terhadap perubahan tingkat motivasi kerja pada pekerja outsourcing. Jenis desain eksperimen yang digunakan pada penelitian ini adalah penelitian eksperimen murni. Menurut Latipun (2006:121) eksperimen murni merupakan desain eksperimen yang paling ideal untuk mempelajari mekanisme hubungan sebab akibat dengan ciri khas yang menjadi kriteria asensi desain eksperimen murni ini ialah mengelompokkan subjek dilakukan dengan teknik random (random assignment).

Pada penelitian ini mengambil jenis desain eksperimen ulang (pretest-posttest control group design). Dimana kelompok eksperimen diberikan pretest sebelum diberi perlakuan yang kemudian diukur dengan posttest setelah perlakuan (Latipun, 2006:122-123). Pada desain ini, dilakukan randomisasi sebagai kontrol, dengan menggunakan random sederhana (simple random) (Latipun, 2006: 49). Skema desain ini sebagai berikut: 
$\begin{array}{ll}\mathrm{R}(\mathrm{KE}) & \mathrm{O}_{1} \rightarrow \mathrm{X} \rightarrow \mathrm{O}_{2} \\ \mathrm{R}(\mathrm{KK}) & \mathrm{O}_{1} \rightarrow \rightarrow \mathrm{O}_{2}\end{array}$

$\mathrm{R} \quad$ : Randomisasi (Random Assigment)

KE : Kelompok Eksperimen

KK : Kelompok Kontrol

$\mathrm{X}$ : Perlakuan

O1 : Pretest

O2 : Posttest

Peneliti menggunakan desain ini karena adanya randomisasi. Randomisasi adalah memasukkan subjek penelitian secara acak ke dalam masing-masing kelompok penelitian (kelompok eksperimen dan kelompok kontrol) (Seniati 2005:28).

Setelah diberikan pelatihan motivasi pada pekerja yang memiliki motivasi kerja yang rendah maupun sedang, akan diukur kembali menggunakan skala motivasi kerja yang sama dengan skala awal ketika sebelum diberikannya perlakuan. Dengan demikian akan terlihat ada atau tidaknya pengaruh perlakuan terhadap variabel terikat. Hal ini dapat diketahui dengan melihat selisih skor pretest dan posttest.

Posedur penelitian meliputi semua kegiatan yang akan dilakukan dalam penelitian, mulai dari awal hingga berakhirnya pelaksanaan penelitian. Peneliti membagi tiga tahap pada penelitian ini, yaitu:

a. Tahap Persiapan

Tahap ini merupakan tahap persiapan yang diperlukan ketika diadakannya penelitian. Peneliti menyiapkan modul, subjek penelitian, tempat dan waktu pelaksanaan penelitian, trainer untuk memberikan perlakuan pada subjek dan skala motivasi kerja untuk mengukur tingkat motivasi kerja yang dikategorikan menjadi rendah dan tinggi. Pretest dilakukan seminggu sebelum diberikannya perlakuan atau pelatihan motivasi. Untuk menghindari pembelajaran skala, peneliti memberi batas tertentu pada saat pengisian skala motivasi kerja yaitu selama 15 menit.

b. Tahap Pelaksanaan

Setelah diketahui tingkat motivasi kerja pekerja maka pekerja yang memiliki motivasi kerja yang rendah maupun sedang diberikan pelatihan motivasi oleh trainer. Trainer yang menyampaikan materi pelatihan adalah seseorang yang memiliki kualifikasi dan telah berpengalaman sebagai trainer.

Pelatihan motivasi dilaksanakan seharian yaitu dimulai dari pukul $08.00 \mathrm{~s} / \mathrm{d} 15.30 \mathrm{WIB}$. Pelatihan dimulai dengan pembukaan oleh tim leader atau yang disingkat menjadi $T L$, kemudian diserahkan kepada trainer yang diawali dengan ice breaking sebut nama tujuannya adalah agar masing-masing peserta memperkenalkan diri. Kemudian dilanjutkan pengenalan mengenai pelatihan motivasi. Sebelum masuk kepada penyampaian materi peserta pelatihan diinstruksikan untuk menulis sesuatu yang ingin dicapai dan apa yang memotivasi mereka untuk bekerja selama 
ini. Setelah itu dilanjutkan pelaksanaan pelatihan motivasi dengan penyampaian materi teori motivasi kerja yang diselingi video. Agar peserta tetap konsentrasi dilakukan ice breaking. Dilanjutkan kembali pemberian materi pada pelatihan motivasi. Setelah itu ice breaking sama gerak untuk mengembalikan kembali konsentrasi peserta. Setelah itu pemberian kembali materi berdasarkan Al-quran dan Hadist. Kemudian break untuk memberikan waktu istirahat kepada trainer, peserta, peneliti dan tim. Dilanjutkan kembali pelatihan motivasi dengan pemberian materi Standar Operasional Prosedur Kebersihan. Setelah penyampaian materi pelatihan motivasi, dilakukan ice breaking balon musik untuk mengevaluasi kembali tugas dan tanggung jawab peserta pelatihan sebagai pekerja outsourcing yaitu sebagai cleaning service. Peneliti melakukan posttest dengan memberikan skala motivasi kerja yang sama dengan saat diberikannya pretest. Disamping itu, peneliti juga melakukan evaluasi pelatihan dengan memberikan kuisioner pelatihan yang langsung diisi oleh peserta pelatihan. Setelah itu pelatihan motivasi ditutup.

c. Tahap Evaluasi

Tahap ini merupakan tahap evaluasi. Penelitian ini perlu adanya persiapan yang matang sebelum diadakannya pelatihan. Ketika peneliti telah merasa siap dengan persiapan untuk melakukan penelitian salah satunya berupa pemberian treatment yaitu pelatihan, maka pelatihan akan dilakukan. Perlu adanya evaluasi dari pelaksanaan pelatihan. Salah satu yang dilakukan untuk mengetahui apakah pelatihan berjalan dengan lancar atau tidak, peserta diberikan kuesioner terkait kelancaran pelatihan motivasi yang kemudian diisi oleh peserta.

Teknik Pengumpulan Data

1. Wawancara

2. Observasi

3. Skala Motivasi Kerja

Data dalam penelitian ini dikumpulkan dengan menggunakan skala motivasi kerja. Skala yang peneliti gunakan adalah skala Likert. yang akan diukur dijabarkan menjadi indikator. Kemudian indikator tersebut dijadikan sebagai titik tolak untuk menyusun aitem-aitem instrumen yang dapat berupa pernyataan atau pertanyaan.

Analisis data yang digunakan pada penelitian ini adalah analisis Uji Man- Whitney U-Test dan Uji Friedman, dengan pengukuran statistik Nonparametrik dengan alasan karena data penelitian tidak terdistribusi normal. Uji Man-Whitney $U$ - Test digunakan untuk mengetahui signifikansi perbedaan antara kelompok eksperimen yang diberikan treatment dengan kelompok kontrol yang tidak diberikan treatment. Sedangkan Uji Friedman digunakan untuk mengetahui signifikansi perbedaan skor motivasi kerja pada saat prepost dan posttest kelompok eksperimen dan kelompok kontrol.

\section{Hasil dan Pembahasan}

Berdasarkan analisis kuantitatif dapat diketahui tingkat signifikansi sebesar 0,000, dikarenakan tingkat signifikansi lebih kecil dari tingkat kesalahan $(0,000>0,05)$ dengan kata lain terdapat perbedaan tingkat motivasi kerja antara kelompok eksperimen dengan kelompok kontrol. Dimana pada kelompok eksperimen rata-rata peningkatan tingkat motivasi kerja yaitu 21,33, sedangkan pada kelompok kontrol peningkatan tingkat motivasi kerjanya adalah 9,67. Dapat disimpulkan bahwa terdapat perbedaan peningkatan motivasi kerja pekerja outsourcing 
yang signifikan setelah diberikan pelatihan motivasi. Hipotesis penelitian ini diterima, yaitu pelatihan motivasi dapat meningkatkan motivasi kerja pekerja outsourcing.

a) Uji Friedman Kelompok Eksperimen

Pada hipotesis yang dirumuskan oleh peneliti bahwa terdapat peningkatan motivasi kerja pekerja outsourcing sebagai cleaning service di UIN Imam Bonjol Padang antara skor pretest dengan posttest pada kelompok eksperimen. Hasil analisis yang dilakukan menunjukkan tingkat signifikansi sebesar 0,000. Dikarenakan tingkat signifikansi lebih kecil dari tingkat kesalahan $(0,000<0,005)$ maka hipotesis diterima. Dengan kata lain terdapat perbedaan peningkatan tingkat motivasi kerja pekerja outsourcing sebagai cleaning service di UIN Imam Bonjol Padang setelah diberikan treatment berupa pelatihan motivasi. Kemudian dapat diketahui bahwa tingkat motivasi kerja kelompok eksperimen meningkat, dimana pretest menunjukkan mean rank sebesar 1,03, kemudian meningkat pada posttest sebesar 1,97.

b) Uji Friedman Kelompok Kontrol

Pada hipotesis yang dirumuskan oleh peneliti bahwa tidak terdapat peningkatan motivasi kerja pekerja outsourcing sebagai cleaning service di UIN Imam Bonjol Padang antara skor pretest dengan posttest pada kelompok kontrol. Hipotesis akan ditolak jika tingkat signifikan lebih kecil dari tingkat kesalahan dengan nilai 0,05. Hasil analisis yang dilakukan menunjukkan tingkat signifikansi sebesar 0,796. Dikarenakan tingkat signifikansi lebih besar dari tingkat kesalahan $(0,796>0,005)$ maka hipotesis diterima. Dengan kata lain tidak terdapat peningkatan motivasi kerja pekerja outsourcing sebagai cleaning service di UIN Imam Bonjol Padang. Kemudian dapat diketahui bahwa tingkat motivasi kerja kelompok kontrol tidak mengalami peningkatan, dimana pretest menunjukkan mean rank sebesar 1,53, kemudian menurun pada posttest sebesar 1,47 .

Perbedaan Uji Friedman antara kelompok eksperimen dan kelompok kontrol dapat diketahui: 


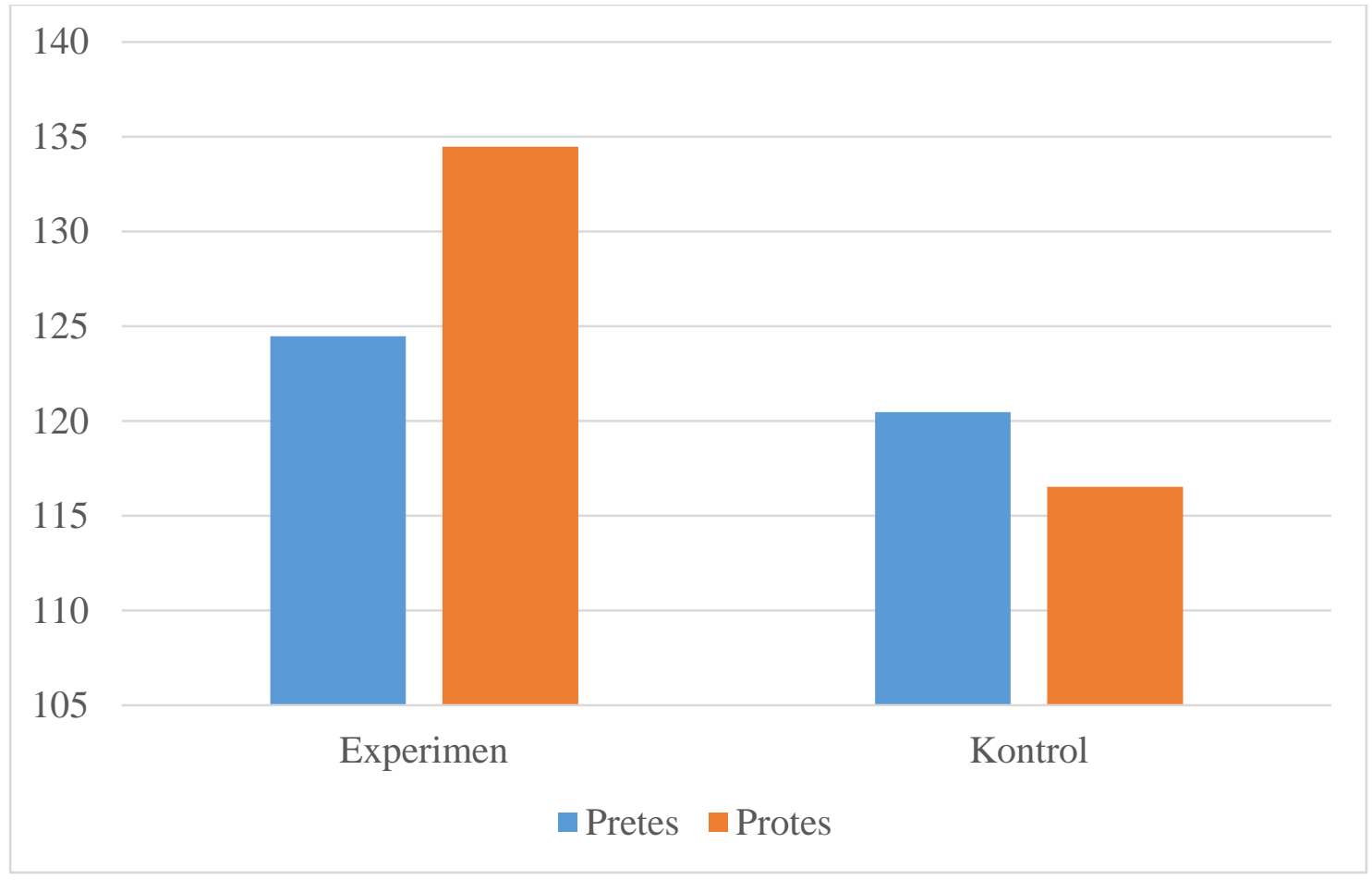

Gambar 2 Perbandingan Mean Score Antara Kelompok Eksperimen dan Kelompok Kontrol

Gambar 2 menunjukkan adanya peningkatan skor rata-rata dari motivasi kerja dengan menggunakan skala motivasi kerja pada pretest dan posttest, kelompok eksperimen dan kelompok kontrol. Pada kelompok eksperimen menunjukkan meanscore pretest sebesar 124,47 dan pada posttest 134,47 . Sedangkan pada kelompok kontrol menunjukkan mean score pretest sebesar 120,47 dan pada posttest 116,53.

Dari hasil penelitian menunjukkan bahwa terdapat perbedaan yang signifikan antara motivasi kerja kelompok eksperimen yang diberikan treatment berupa pelatihan motivasi dengan kelompok kontrol yang tidak diberikan pelatihan motivasi. Berdasarkan hasil uji man whitney antara kelompok ekperimen dan kelompok kontrol menunjukkan bahwa secara keseluruhan terdapat perbedaan tingkat signifikansi. Sedangkan pada uji friedman pada kelompok eksperimen menunjukkan bahwa ada perbedaan tingkat motivasi kerja yang sangat signifikan antara pretest dengan posttest, maka terdapat perbedaan peningkatan tingkat motivasi kerja pekerja outsourcing setelah diberikan treatment berupa pelatihan motivasi.

Berdasarkan hasil penelitian ini dapat disimpulkan bahwa treatment berupa pelatihan motivasi dapat meningkatkan motivasi kerja pekerja outsourcing. Hasil penelitian ini mendukung penelitian terdahulu, berdasarkan penelitian Rini dan Widiana (2011: 77) menunjukkan perbedaan peningkatan produktivitas kerja karyawan yang sangat signifikan antara kelompok eksperimen yang mendapatkan pelatihan motivasi dengan kelompok kontrol yang tidak mendapatkan pelatihan motivasi. Hal tersebut menunjukkan bahwa pelatihan motivasi efektif untuk meningkatkan produktivitas. 
Hasil penelitian juga didukung dengan teori dimana motivasi dapat diberikan melalui pelatihan (training), Menurut Rivai \& Sagala (2013:212-233) pelatihan adalah proses secara sistematis mengubah tingkah laku pegawai untuk mencapai tujuan organisasi. Kasmir (2016:126) juga menyatakan bahwa pelatihan merupakan proses untuk membentuk dan membekali karyawan dengan menambah keahlian, kemampuan, pengetahuan dan perilakunya. Sedangkan motivasi kerja menurut Anoraga (2009:35-40) adalah sesuatu yang menimbulkan semangat atau dorongan kerja. Menurut Usman (2013:276) motivasi kerja diartikan sebagai keinginan atau kebutuhan yang melatarbelakangi seseorang sehingga ia terdorong untuk bekerja.

Pelatihan memiliki orientasi saat ini dan membantu pegawai untuk mencapai keahlian dan kemampuan tertentu agar berhasil dalam melaksanakan pekerjaannya. Sedangkan program pelatihan formal adalah usaha pemberi kerja untuk memberikan kesempatan kepada pegawai untuk memperoleh pekerjaan atau bidang tugas yang sesuai dengan kemampuan, sikap dan kemampuannya. Menurut Rini \& Widiana (2011:8) pelatihan motivasi adalah suatu kegiatan yang bermaksud untuk dapat memperbaiki dan memperkembangkan sikap, tingkah laku, keterampilan dan pengetahuan dari para karyawan, sesuai keinginan dari perusahaan yang bersangkutan untuk mendorong seseorang melakukan serangkaian kegiatan yang mengarah tercapainya tujuan tertentu.

Motivasi tersebut juga mendasari pekerja outsourcing. Outsourcing (Restu, 2011:1) diartikan sebagai pemindahan atau pendelegasian berbagai proses bisnis kepada suatu badan penyedia jasa, dimana badan penyedia jasa tersebut melakukan proses administrasi dan manajemen berdasarkan definisi serta kriteria yang telah disepakati oleh para pihak. Dalam perkembangannya, perusahaan yang menggunakan system outsourcing akan menyebabkan kedudukan dan hubungan kerja antara pekerja dan pengusaha menjadi tidak seimbang. Hal ini berdampak kepada posisi pekerja menjadi semakin lemah karena tidak ada kepastian kerja, kepastian upah, jaminan sosial, jaminan kesehatan, pesangon, jika terjadi pemutusan hubungan kerja, tunjangan- tunjangan dan kepastian lainnya.Selanjutnya praktek outsourcing lebih menguntungkan bagi perusahaan tetapi tidak demikian dengan pekerja yang selama ini lebih banyak dirugikan, karena hubungan kerja selalu dalam bentuk tidak tetap atau kontrak, upah lebih rendah, jaminan sosial kalaupun ada hanya sebatas minimal, tidak adanya job security serta tidak adanya jaminan pengembangan karir, sehingga dalam keadaan seperti itu pelaksanaan outsourcing menyengsarakan pekerja. Pelaksanaan outsourcing banyak dilakukan untuk menekan biaya pekerja (labour cost) dengan perlindungan dan syarat kerja yang diberikan jauh dibawah dari yang seharusnya diberikan sehingga sangat merugikan perkerja.

Salah satu upaya mencarai rezeki dalah bekerja sebagai buruh atau penyedia jasa. Seluruh perusahaan dan mata-pencaharian yang dapat menutupi kebutuhan masyarakat atau yang dapat mendatangkan manfaat yang nyata, semua itu termasuk amal sholeh apabila semua itu dilakukan dengan ikhlas dan dilaksanakan menurut perintah agama. Islam menganggap tinggi beberapa pekerjaan yang kadang-kadang oleh manusia dinilai sangat rendah. Bahkan mereka tidak mau menganggapnya sebagai pekerjaan yang baik. Sebagaimana dalam kisah dan sabda yang disampaikan Rasulullah SAW ketika itu menggembala kambing,

"Allah tidak mengutus seorang Nabi pun melainkan dia itu mengembala kambing." Waktu para sahabat mendengarkan perkataan itu, mereka kemudian bertanya, "Dan engkau ya Rasulullah?" 
Jawab Nabi, "Ya, saya juga mengembala kambing dengan upah beberapa karat, milik penduduk Makkah.” (Riwayat Bukhari)

Nabi Muhammad sebagai utusan Allah dan penutup sekalian Nabi. Tetapi disamping itu, ia juga sebagai pengembala kambingmilik penduduk Mekah untuk mendapatkan upah (Ayyash, 2008:79-80).

Faktor pendukung dari penelitian juga dipengaruhi pada pelaksanaan pelatihan motivasi. Berdasarkan kuisioner pelaksanaan pelatihan yang telah diisi oleh peserta menunjukkan bahwa pelatihan motivasi yang dilakukan sangat baik, dengan penilaian jadwal terorganisir dengan baik, materi atau pengetahuan sesuai kebutuhan, memberi semangat dan menambah pengetahuan kebersihan, metode yang digunakan sangat baik, proses pelatihan motivasi berlangsung

dengan baik, dan pemateri dapat menyampaikan materi dengan sangat baik.

\section{Simpulan dan Saran}

Hasil kesimpulan ini merujuk pada rumusan masalah yaitu seberapa tinggi tingkat motivasi kerja pekerja outsoucing sebelum dilakukannya pelatihan motivasi, seberapa tinggi tingkat motivasi kerja pekerja outsoucing setelah dilakukannya pelatihan motivasi, adakah pengaruh pelatihan motivasi terhadap motivasi kerja pekerja outsourcing dan apakah pelatihan yang diadakan berlangsung lancar atau tidak bagi peserta pelatihan.

1. Berdasarkan hasil pretest yang dilakukan kepada kelompok eksperimen dan kelompok kontrol menunjukkan motivasi kerja subjek tidak ada perbedaan, yaitu secara keseluruhan subjek memiliki motivasi kerja pada kategori sedang, dengan skor kecil dari 137.

2. Hasil posttest yang dilakukan kepada kelompok eksperimen mengalami peningkatan secara signifikan setelah diberikan treatment berupa motivasi kerja. Sementara pada kelompok kontrol yang tidak diberi treatment berupa pelatihan motivasi, tidak menunjukkan adanya peningkatan secara signifikan. Bahkan terjadi penurunan pada beberapa anggota kelompok kontrol.3. Pengaruh dari pemberian treatment berupa pelatihan motivasi, dimana terdapat perbedaan antara prepost dan posttest kelompok eksperimen, yaitu terjadi peningkatan motivasi kerja. Sedangkan pada kelompok kontrol yang tidak diberikan pelatihan motivasi, menunjukkan tidak adanya perbedaan secara signifikan atau bahkan mengalami penurunan. Hal tersebut dapat disimpulkan bahwa adanya pengaruh pelatihan motivasi terhadap motivasi kerja pekerja outsourcing pada kelompok eksperimen.

Berdasarkan kuisioner pelaksanaan pelatihan yang telah diisi oleh peserta dapat disimpulkan bahwa pelatihan motivasi yang dilakukan sangat baik, dengan penilaian jadwal terorganisir dengan baik, materi atau pengetahuan sesuai kebutuhan, memberi semangat dan menambah pengetahuan kebersihan, metode yang digunakan sangat baik, proses pelatihan motivasi berlangsung dengan baik, dan pemateri dapat menyampaikan materi dengan sangat baik.

Berdasarkan hasil penelitian ini, peneliti mengharapkan adanya pemanfaatan penelitian ini dan seterusnya penelitian ini dapat menjadi bahan untuk melanjutkan penelitain seterusnya.

\section{Daftar Pustaka}


Afrianti F. (2012). Pengaruh Motivasi Kerja Dan Komunikasi Interpersonal Terhadap Kinerja Guru Pada SMA N 6 Kerinci Kecamatan Danau Kerinci, Tesis UPI-YPTK Padang. Tesis dipublikasikan

Anggraeni E. Pengaruh Motivasi, Pelatihan Kerja dan Kompensasi Terhadap Produktivitas Layanan Frontliner BCA KCU SemarangAnoraga P. (2009). Psikologi Kerja, cetakan ke-lima, Jakarta: PT. RINEKA CIPTA

Azwar S. (2013). Penyusunan Skala Psikologi, Yogyakarta: Pustaka Pelajar

Ardana K, dkk. (2008). Perilaku Keorganisasian, Yogyakarta: Graha Ilmu

Ayyash M. A. (2008) Keajaiban Shalat Dhuha, Jakarta: Qultum Media

Budiartha G. N, dkk. (2015). Pengaruh Pelatihan Dan Motivasi Kerja Terhadap Produktivitas Kerja Karyawan. Jurnal Bisma Universitas Pendidikan Ganesha Jurusan Manajemen Volume 3

BPS. (2013). Jumlah UMP Tahun 2008- 20013 Di Sumatera Barat: BPS BPS. (2014). Keadaan Pekerja Di Indonesia Februari 2014, Jakarta : BPS Departemen Agama RI. 2005, Al Quran dan Terjemahannya, Ban dung : Diponegoro

Gomes F.C. (2002). Manajemen Sumber Daya Manusia, Yogyakarta: Andi Offset.http://bisnis. liputan6. com/r ead /2428536/ kspi-perkirakan-akan -ada-phk besar di unduh 13 Juni 2016

http://bisnis. liputan6.com/ read/2517422/ buruh-tuntut-ump-2017-naik-rp-650-ribu-inialasannya, di unduh 13 Juni 2016 http://news.liputan6.com/read/2497884/kembaliberdemo-di-istana-buruh- tuntut- upahmurahdihapus?utm_source=Se arch\&utm_medium=SiteSearch\&ut m_campaign=Original, di unduh 13 Juni 2016.

Hasibuan M.S.P. (2003). Organisasi Dan Motivasi, Cetakan Ke-Empat, Jakarta: PT. Bumi Aksara

Hermanto B. (2012). Pengaruh Prestasi Training Motivasi, Dan Masa Kerja Teknisi Terhadap Produktivitas Teknisi Di Bengker Nissa Yogtakarta, Solo Dan Semarang

Hurlock E. B. (2002). Psikologi Perkembangan, Jakarta: Erlangga

Indrawijaya A.I. (1989). Perilaku Organisasi, Cetakan Ke-Empat, Bandung: Sinar Baru Bandung

Kasmir. (2016). Manajemen Sumber Daya Manusia, Jakarta: PT. Raja Grafindo Persada

Latipun. (2006). Psikologi Eksperimen, Malang: Universitas Muhammadiyah Malang

Lumingas N. (2013). Perlindungan Hukum Terhadap Pekerja Outsourcing, Lex at Sociertatis. Volume 1. No 2

Mangkunegara A.A.A.P. (2009). Manajemen Sumber Daya Manusia Perusahaan, Cetakan KeSembilan, Bandung : PT. Remaja Rosdakarya

Munandar A.S. (2008), Psikologi Industri dan Organisasi, Jakarta: UI-Press

Narbuko C \& Achmadi A. (2015).

Metodologi Penelitian, Cetakan Ke- Empat Belas, Jakarta: Bumi Aksara 
Restu K. (2011). Perlindungan Hukum Terhadap Pekerja Outsourcing (Alih Daya) Pada PT.Sucofindo, Fakultad Hukum Universitas Andalas

Rini T. N \& Widiana H. S. (2001). Efektivitas Pelatihan Motivasi Terhadap Peningkatan Produktivitas Karyawan Bagian Expecting PT X, Fakultas Psikologi Universitas Ahmad Dahlan Volume 3. No 2

Rivai V \& Sagala E.J. (2013). Manajemen Sumber Daya Manusia Untuk Perusahaan. Cetakan Ke-Lima, Jakarta: PT. Raja Grafindo Persada

Seniati L dkk. (2005). Psikologi Eksperimen, Jakarta: PT.INDEKS

Siagian SP. (2009), Kiat Meningkatkan Produktivitas Kerja, Cetakan Ke- Dua, Jakarta: Rineka Cipta

Sugesti. (2012). Pengaruh Pelatihan Guru dan Motivasi Kerja Terhadap Kinerja Guru Pada SMP Negeri, Tesis UPI-YPTK Padang

Sugiyono. (2010). Metode Penelitian Kuantitatif, Cetakan Ke-Sebelas, Jakarta: ALFABETA (2011). Metode Penelitian Kuantitatif, Cetakan Ke-Tigabelas, Jakarta: ALFABETA

Sule E.T \& Saefullah K. (2010). Pengantar Manajemen, Cetakan Ke-Lima, Jakarta: Prenada Media Group

Sulistiyani A.T \& Rosidah. (2009).

Manajemen Sumber Daya Manusia, Edisi Ke-DuaYogyakarta : Graha Ilmu

Terry G. R \& Rue L. W. (2010). Dasar-Dasar Manajemen, Cetakan Ke- Sebelas Jakarta: PT. Bumi Aksara.

Tunggal A.W. (1995). Kamus Akuntansi,Jakarta: PT. Rineka Cipta Ulfah E. (2013). Intervensi Spiritual Emotional Freedom Techniqu

Untuk Menurunkan Gangguan Stres Pasca Trauma Pada Remaja Korban Erupsi Gunung Merapi, Tesis Universitas Ahmad Dahlan Yogyakarta.

Usman H. (2013). Manajemen,Edisi Ke- Empat, Jakarta: PT. Ikrar Mandiriabadi

Wahjosumidjo. (1987). Kepemimpinan dan Motivasi, Cetakan Ke-Tiga, Jakarta: Ghalia Indonesia

Wexley K.N \& Yukl G.R. (2005). Perilaku Organisasi dan Psikologi Personalia, Cetakan Ke-Tiga, Jakarta: PT. Rineka Citra

Wijono S.( 2014). Psikologi Industri dan Organisasi (dalam suatu bidang gerak psikologi sumber daya manusia), Cetakan Ke-Empat, Jakarta: Kencana Prenada Media Group 